\title{
Evidence for the Use of Secukinumab in Patients with Radiographic and Non-radiographic Axial Spondyloarthritis in the Last 5 Years
}

\author{
María Aparicio · Carlos A. Guillén-Astete · Clementina López-Medina • \\ Carlos Sastre · Fernando J. Rodríguez Martínez
}

Received: October 8, 2021 / Accepted: November 9, 2021 / Published online: November 27, 2021

(C) The Author(s) 2021

\begin{abstract}
Axial spondyloarthritis (axSpA) is an inflammatory rheumatic disorder that causes chronic pain, primarily in the spine and sacroiliac joints. It is characterized by the presence of type 1 major histocompatibility complex HLA-B27 genetic marker, arthritis in peripheral joints, enthesitis and/or dactylitis and extra-articular manifestations. Current guidelines recommend biological therapy when first-line therapy is not sufficiently effective. The finding that the interleukin (IL)-17 axis is vital for the pathogenesis of axSpA propelled the development of secukinumab, a fully human monoclonal
\end{abstract}

\author{
M. Aparicio \\ Rheumatology Service, Hospital Universitario \\ Germans Trias i Pujol, Barcelona, Spain \\ C. A. Guillén-Astete \\ Rheumatology Service, Hospital Universitario \\ Ramón y Cajal, Madrid, Spain \\ C. López-Medina \\ Department of Rheumatology, Hospital \\ Universitario Reina Sofía, Maimonides Institute of \\ Biomedical Research of Cordoba (IMIBIC) and \\ University of Córdoba, Córdoba, Spain \\ C. Sastre \\ Novartis Farmaceutica S.A., Barcelona, Spain \\ F. J. Rodríguez Martínez ( $\square$ ) \\ Department of Rheumatology, Complejo \\ Hospitalario de Cartagena, Cartagena, Spain \\ e-mail: fernandordmt@gmail.com
}

antibody directed against IL-17A. The present review provides evidence on the efficacy and safety of secukinumab in the treatment of radiographic and non-radiographic axSpA from nine randomized controlled phase III trials, as well as evidence from real-world observational analyses. The primary endpoint in six clinical trials was the proportion of patients meeting the Assessment of SpondyloArthritis international Society criteria for either $20 \%$ or $40 \%$ improvement (ASAS20, ASAS40) at week 16. Significantly more patients achieved the primary endpoint with secukinumab compared with placebo in all the studies except MEASURE 4. Both clinical trials and real-world studies showed significant improvements in the secondary endpoints of disease activity, quality of life, and pain and fatigue relative to placebo. The benefits of secukinumab were generally sustained during longer-term (up to 5 years) treatment. Overall, secukinumab was well tolerated with a low frequency of adverse events and treatment persistence was high in the realworld setting. Although indirect comparisons suggest that secukinumab and adalimumab have comparable efficacy and safety, they are being directly compared in the ongoing SURPASS study. During the current coronavirus disease 2019 (COVID-19) pandemic, it is advisable to continue biological therapy in patients who do not have severe acute respiratory syndrome coronavirus 2 (SARS-CoV2) infection, but interrupt treatment during an infection, 
reinitiating once the patient has recovered from the infection. In conclusion, secukinumab is a largely safe and effective treatment for radiographic and non-radiographic axSpA.

Keywords: Assessment of SpondyloArthritis international Society; Axial spondyloarthritis; Biological therapy; Inflammation; Interleukin17A; Sacroiliitis; Secukinumab

\section{Key Summary Points}

This review describes the current evidence supporting the efficacy and safety of secukinumab, a first-in-class interleukin (IL)-17A inhibitor, in the treatment of musculoskeletal manifestations of axial spondyloarthritis (axSpA).

Secukinumab demonstrated both shortand long-term efficacy (up to 5 years) in the treatment of radiographic and nonradiographic axSpA and significantly improved patient quality of life and work productivity.

Secukinumab is well tolerated with a low frequency of adverse events and high treatment persistence in a real-world setting.

Indirect comparisons suggest that the efficacy and safety profile of secukinumab is consistent with that of tumor necrosis factor inhibitors.

\section{INTRODUCTION}

The term 'spondyloarthritis' is used to define a group of rheumatic disorders, characterized by a genetic association with type 1 major histocompatibility complex HLA-B27, extra-articular manifestations, and common clinical characteristics [1]. The group of spondyloarthropathies include axial spondyloarthritis $(\operatorname{axSpA})$, psoriatic arthritis (PsA), reactive

arthritis, and arthritis related to inflammatory bowel disease (IBD) [2].

When the conditions primarily affect the sacroiliac joints, with or without the involvement of the spine, they are termed axSpA $[1,3]$. The predominant clinical feature of axSpA is chronic back pain, which may be accompanied by arthritis in peripheral joints, enthesitis and/ or dactylitis, as well as extra-articular manifestations, such as uveitis or psoriasis [1]. Ankylosing spondylitis (AS) is the classical form of axSpA characterized by structural damage to the spine and sacroiliac joints that is visible on radiographic imaging [2]. Patients may or may not show sacroiliitis on X-ray; depending on the presence or absence of significant (grade $\geq 2$ ) sacroiliitis, axSpA can be classified either as radiographic axSpA (r-axSpA) or non-radiographic axSpA (nr-axSpA) [4]. For the most part, the severity of signs and symptoms and the degree of daily life impairment are similar in both the forms of axSpA. However, patients with nr-axSpA tend to be younger and have a shorter disease duration, and are more likely to have enthesitis or tender joints, compared with $\mathrm{r}$-axSpA patients, whereas patients with $\mathrm{r}$-axSpA tend to have worse spinal mobility [5].

In the current European and United States (US) guidelines, which were last updated in 2016 and 2019, respectively, recommendations for the treatment of radiographic and non-radiographic forms of axSpA are similar $[4,6]$. Both sets of guidelines recommend the use of biological therapy in patients with persistently active disease despite treatment with conventional first-line therapy [non-steroidal anti-inflammatory drugs (NSAIDs)] [4, 6]. During the formulation of the guidelines, tumor necrosis factor (TNF) inhibitor therapy was preferred over secukinumab because considerable evidence on the safety and long-term efficacy of TNF inhibitor in axSpA was available, whereas there were limited clinical data for secukinumab in AS and none available in nr-axSpA. Taking this into account, the task force recommended TNF inhibitor as the first biological diseasemodifying antirheumatic drug (bDMARD) for current practice [4].

Secukinumab is the first-in-class interleukin (IL)-17A inhibitor, and is approved for the 
treatment of r-axSpA and nr-axSpA, as well as psoriasis and PsA in the US and Europe [7, 8]. Secukinumab has been used to treat more than 500,000 patients across its four approved therapeutic indications worldwide since its launch (Novartis, Data on File). The aim of the current article is to review the evidence, from both randomized clinical trials and real-world observational analyses, supporting the efficacy and safety of secukinumab in the treatment of musculoskeletal manifestations of $\mathrm{r}-\mathrm{axSpA}$ and nr-axSpA, focusing on the last 5 years of data.

\section{METHODS}

We conducted a PubMed search on April 30, 2021 using the search terms "secukinumab" and "axial" and "spondyl*". Potentially relevant articles were chosen based on the title and abstract. Additionally, we searched for relevant abstracts presented at the annual congresses of the European League Against Rheumatism (EULAR) and the American College of Rheumatology (ACR) held between 2016 and 2021. This review is based on previously conducted studies and does not contain any studies with human participants or animals performed by any of the authors therefore ethical approval was not required.

\section{Key Pharmacological Properties of Secukinumab}

\section{Mechanism of Action}

Secukinumab is a fully human monoclonal antibody directed against IL-17A [9], the best characterized member of the superfamily of IL17 ligands [10]. Once bound to its receptor, IL17A upregulates inflammatory genes, leading to the release of pro-inflammatory cytokines (including TNF- $\alpha$, IL- 6 and IL-1 $\beta$ ), chemokines (e.g., CXCL-1, -2 and -8), antimicrobial peptides, matrix metalloproteinases, and other inflammatory effector molecules, such as acutephase proteins and complement proteins [11]. Together, these molecules potentiate a positive feedback loop that accelerates and augments the inflammatory response [11]. The IL-17 axis has been shown to play a major role in the pathogenesis of axSpA, and may in fact be more prominent in its pathogenesis than TNF- $\alpha$ $[10,11]$. This led to the clinical development and eventual approval of secukinumab in axSpA (Fig. 1).

\section{Recommended Dosage}

Secukinumab is available in two dosage forms (150 or $300 \mathrm{mg}$ ), which provides physicians with some flexibility to titrate the dose according to the response. In Europe, the recommended starting dose in r-axSpA and nr-axSpA is $150 \mathrm{mg}$ once weekly for the first five doses and then $150 \mathrm{mg}$ per month thereafter [7]. The approved secukinumab dosage is similar in the US, except that the loading dose is optional, and patients can begin treatment with $150 \mathrm{mg}$ every 4 weeks [8]. In both Europe and the US, patients with r-axSpA who have a suboptimal clinical response can be treated with $300 \mathrm{mg} / \mathrm{month}[7,8]$; the higher dose is not currently approved for use in patients with nraxSpA, but is being investigated for this group in the PREVENT extension trial (NCT02696031). Based on data from patients with PsA, patients with enthesitis at baseline and those who have not previously received TNF inhibitor therapy are most likely to achieve an additional benefit from increasing the dose of secukinumab to $300 \mathrm{mg}$ [15].

\section{Secukinumab Clinical Trial Program}

The efficacy and safety of secukinumab for the treatment of axSpA were investigated in at least nine randomized controlled phase III trials (Table 1) [16-23]. The MEASURE studies (1 to 5) included patients with active AS [16, 19-21, 24], the MAXIMISE study was in patients with PsA and spinal involvement [17], the PREVENT study was in patients with nr-axSpA [18], the SKIPPAIN study included patients with axSpA (AS and nr-axSpA) [23], and finally, SURPASS (NCT03259074), which is a study in patients with active AS, is the first head-to-head study comparing the effects of secukinumab versus adalimumab (a TNF inhibitor) [22].

The primary endpoint in the five MEASURE studies and the MAXIMISE study was the 


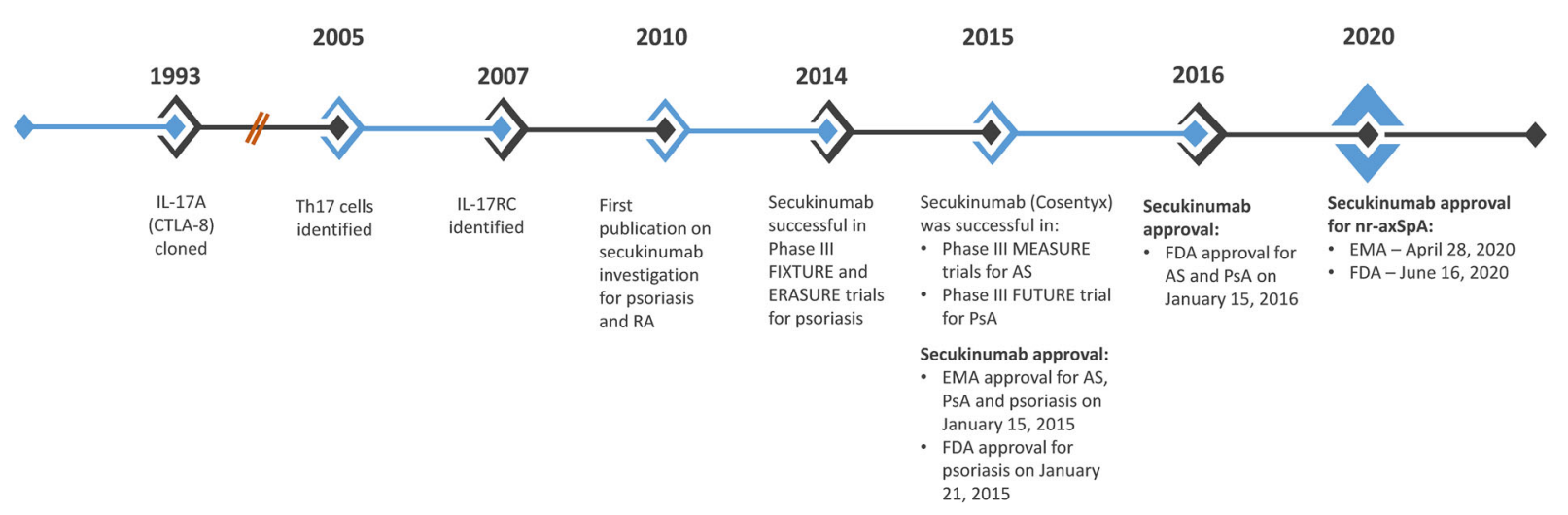

Fig. 1 Timeline for the development and FDA approval of secukinumab [12-14]. Orange lines indicate the developmental phase of secukinumab for RA from 1995 to 2001. AS ankylosing spondylitis; CTLA cytotoxic T-lymphocyte-associated antigen; EMA European Medicines Agency; ERASURE Efficacy of Response and Safety of Two Fixed Secukinumab Regimens in Psoriasis; FDA Food

proportion of patients meeting the Assessment of SpondyloArthritis international Society criteria for $20 \%$ improvement (ASAS20) at week 16 , i.e., an improvement of $\geq 20 \%$ and absolute improvement of $\geq 1$ unit (on a ten-unit scale) in $\geq 3$ of the four main ASAS domains, with $\leq 20 \%$ worsening in the remaining domain $[16,17,19-21,24]$, while it was ASAS40 at week 16 in the PREVENT study [18]. However, SKIPPAIN and SURPASS studies had different primary endpoints; SKIPPAIN is the first study with secukinumab to determine the proportion of patients with a spinal pain numerical rating scale (NRS) score $<4$ at week 8 that was determined using an 11-point NRS [23], and SURPASS measured the proportion of patients with no radiographic progression, i.e., $\mathrm{a} \leq 0.5$ change from baseline in the modified Stoke Ankylosing Spondylitis Spinal Score (mSASSS) at week 104 [22].

\section{Short-Term Efficacy}

In MEASURE 1, 2, and 3, approximately $60 \%$ of patients receiving secukinumab at a maintenance dose of $150 \mathrm{mg}$ achieved the ASAS20 endpoint at week 16, which was significant compared with placebo $(P<0.001$ vs. placebo in MEASURE 1 and 2 and $P<0.05$ vs. placebo in MEASURE 3) [21, 25]. and Drug Administration; FIXTURE Full Year Investigative Examination of Secukinumab vs. Etanercept Using Two Dosing Regimens to Determine Efficacy in Psoriasis; $I L-17$ interleukin 17; $n r$-axSpA non-radiographic axial spondyloarthritis; Ps $A$ psoriatic arthritis; $R A$ rheumatoid arthritis

As in MEASURE 1, 2, and 3, the proportion of patients receiving secukinumab $150 \mathrm{mg}$ (with or without loading doses) who achieved the ASAS20 endpoint at week 16 in MEASURE 4 was $\sim 60 \%$ (59.5\% in the group with loading dose and $61.5 \%$ in group without loading dose), but the proportion of patients who achieved this endpoint in the placebo group was $47 \%$ (i.e., higher than in MEASURE 1, 2, and 3). As a result, the difference in the primary endpoint between the secukinumab and placebo groups in MEASURE 4 did not reach statistical significance $(P=0.057$ and $P=0.054$, respectively) [21]. In MEASURE 5, 58.4\% of patients receiving secukinumab $150 \mathrm{mg}$ achieved the ASAS20 endpoint at week 16 compared with 36.6\% receiving placebo $(P<0.0001)$ [19].

The magnitude and direction of the primary endpoint results from the MEASURE studies have been confirmed in meta-analyses $[26,27]$. Similarly, these studies showed significant improvements in the secondary endpoints of disease activity, such as C-reactive protein (CRP) levels, Ankylosing Spondylitis Disease Activity Score (ASDAS), and Bath Ankylosing Spondylitis Disease Activity Index (BASDAI), relative to placebo [16, 19-21].

The other three studies (PREVENT, MAXIMISE, and SKIPPAIN $[17,18,23]$ ) provide more 
Table 1 The design of the phase III randomized controlled trials of secukinumab in patients with axial spondyloarthritis

\begin{tabular}{|c|c|c|c|c|c|c|}
\hline $\begin{array}{l}\text { Study } \\
\text { acronym }\end{array}$ & Design & Patients & Treatments & $N$ & $\begin{array}{l}\text { Total } \\
\text { duration }\end{array}$ & Primary endpoint \\
\hline $\begin{array}{c}\text { MEASURE } \\
1[16]\end{array}$ & $\begin{array}{c}\mathrm{R}, \mathrm{DB}, \\
\mathrm{PC}\end{array}$ & 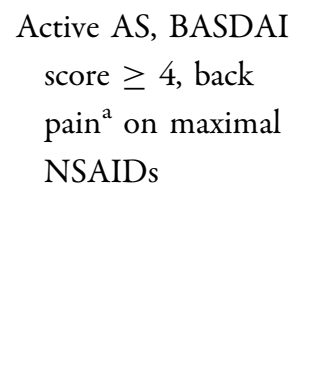 & $\begin{array}{l}\text { Placebo } \\
\text { Secukinumab LD } \\
\text { then } 75 \mathrm{mg} \mathrm{q} 4 \mathrm{w} \\
\text { SC } \\
\text { Secukinumab LD } \\
\text { then } 150 \mathrm{mg} \\
\text { q4w SC }\end{array}$ & $\begin{array}{l}122 \\
124\end{array}$ & 2 years & $\begin{array}{l}\text { Proportion of patients } \\
\text { who met ASAS20 } \\
\text { response criteria at } \\
\text { week } 16\end{array}$ \\
\hline $\begin{array}{c}\text { MEASURE } \\
2[16]\end{array}$ & $\begin{array}{c}\mathrm{R}, \mathrm{DB} \\
\mathrm{PC}\end{array}$ & $\begin{array}{l}\text { Active AS, BASDAI } \\
\text { score } \geq 4 \text {, back } \\
\text { pain }^{\text {a }} \text { on maximal } \\
\text { NSAIDs }\end{array}$ & $\begin{array}{l}\text { Placebo } \\
\text { Secukinumab LD } \\
\text { then } 75 \mathrm{mg} \mathrm{q} 4 \mathrm{w} \\
\text { SC } \\
\text { Secukinumab LD } \\
\text { then } 150 \mathrm{mg} \\
\text { q4w SC }\end{array}$ & $\begin{array}{l}74 \\
73\end{array}$ & 5 years & $\begin{array}{l}\text { Proportion of patients } \\
\text { who met ASAS20 } \\
\text { response criteria at } \\
\text { week } 16\end{array}$ \\
\hline $\begin{array}{l}\text { MEASURE- } \\
\text { 2J [24] }\end{array}$ & $\mathrm{OL}$ & $\begin{array}{l}\text { Japanese patients with } \\
\text { active AS, BASDAI } \\
\text { score } \geq 4 \text {, back } \\
\text { pain }^{\text {a on maximal }} \\
\text { NSAIDs }\end{array}$ & $\begin{array}{l}\text { Secukinumab LD } \\
\text { then } 150 \mathrm{mg} \\
\text { q4w SC }\end{array}$ & 30 & 1 year & $\begin{array}{l}\text { Proportion of patients } \\
\text { who met ASAS20 } \\
\text { response criteria at } \\
\text { week } 16\end{array}$ \\
\hline $\begin{array}{c}\text { MEASURE } \\
3[21]\end{array}$ & $\begin{array}{c}\mathrm{R}, \mathrm{DB} \\
\mathrm{PC}\end{array}$ & $\begin{array}{l}\text { Active AS, BASDAI } \\
\text { score } \geq 4 \text {, back } \\
\text { pain }^{\text {a } ~ o n ~ m a x i m a l ~} \\
\text { NSAIDs }\end{array}$ & $\begin{array}{l}\text { Placebo } \\
\text { Secukinumab LD } \\
\text { then } 150 \mathrm{mg} \\
\text { q4w SC } \\
\text { Secukinumab LD } \\
\text { then } 300 \mathrm{mg} \\
\text { q4w SC }\end{array}$ & $\begin{array}{l}76 \\
74\end{array}$ & 3 years & $\begin{array}{l}\text { Proportion of patients } \\
\text { who met ASAS20 } \\
\text { response criteria at } \\
\text { week } 16\end{array}$ \\
\hline $\begin{array}{c}\text { MEASURE } \\
4[20]\end{array}$ & $\begin{array}{c}\mathrm{R}, \mathrm{DB} \\
\mathrm{PC}\end{array}$ & $\begin{array}{l}\text { Active AS, BASDAI } \\
\text { score } \geq 4 \text {, back } \\
\text { pain }^{\mathrm{a}} \text { on maximal } \\
\text { NSAIDs }\end{array}$ & $\begin{array}{l}\text { Placebo } \\
\text { Secukinumab LD } \\
\text { then } 150 \mathrm{mg} \\
\text { q4w SC } \\
\text { Secukinumab } \\
150 \mathrm{mg} \mathrm{q} 4 \mathrm{w} \mathrm{SC}\end{array}$ & $\begin{array}{l}117 \\
116\end{array}$ & 2 years & $\begin{array}{l}\text { Proportion of patients } \\
\text { who met ASAS20 } \\
\text { response criteria at } \\
\text { week } 16\end{array}$ \\
\hline $\begin{array}{c}\text { MEASURE } \\
5 \text { [19] }\end{array}$ & $\begin{array}{c}\mathrm{R}, \mathrm{DB} \\
\mathrm{PC}\end{array}$ & $\begin{array}{l}\text { Active AS, BASDAI } \\
\text { score } \geq 4, \text { back } \\
\text { pain }^{\mathrm{a}} \text { on } \geq 2 \\
\text { NSAIDs ( } 71.4 \% \\
\text { from China) }\end{array}$ & $\begin{array}{l}\text { Placebo } \\
\text { Secukinumab LD } \\
\text { then } 150 \mathrm{mg} \\
\text { q4w SC }\end{array}$ & $\begin{array}{l}153 \\
305\end{array}$ & 1 year & $\begin{array}{l}\text { Proportion of patients } \\
\text { who met ASAS20 } \\
\text { response criteria at } \\
\text { week } 16\end{array}$ \\
\hline
\end{tabular}


Table 1 continued

\begin{tabular}{|c|c|c|c|c|c|c|}
\hline $\begin{array}{l}\text { Study } \\
\text { acronym }\end{array}$ & Design & Patients & Treatments & $N$ & $\begin{array}{l}\text { Total } \\
\text { duration }\end{array}$ & Primary endpoint \\
\hline $\begin{array}{l}\text { MAXIMISE } \\
{[17]}\end{array}$ & $\begin{array}{l}\mathrm{R}, \mathrm{DB}, \\
\mathrm{PC}\end{array}$ & $\begin{array}{l}\text { Active spinal PsA, } \\
\text { BASDAI score } \geq 4 \text {, } \\
\text { back pain }{ }^{\mathrm{a}} \text { on } \geq 2 \\
\text { NSAIDs }\end{array}$ & $\begin{array}{l}\text { Placebo } \\
\text { Secukinumab LD } \\
\text { then } 150 \mathrm{mg} \\
\text { q4w SC } \\
\text { Secukinumab LD } \\
\text { then } 300 \mathrm{mg} \\
\text { q4w SC }\end{array}$ & $\begin{array}{l}166 \\
165\end{array}$ & 1 year & $\begin{array}{l}\text { Proportion of patients } \\
\text { who met ASAS20 } \\
\text { response criteria at } \\
\text { week } 12\end{array}$ \\
\hline $\begin{array}{l}\text { PREVENT } \\
{[18]}\end{array}$ & $\begin{array}{l}\mathrm{R}, \mathrm{DB}, \\
\mathrm{PC}\end{array}$ & $\begin{array}{l}\text { Active nr-axSpA with } \\
\text { objective signs of } \\
\text { inflammation (MRI } \\
\text { with SI joint } \\
\text { inflammation and/ } \\
\text { or hsCRP > ULN) }\end{array}$ & $\begin{array}{l}\text { Placebo } \\
\text { Secukinumab LD } \\
\text { then } 150 \mathrm{mg} \\
\text { q4w SC } \\
\text { Secukinumab } \\
150 \mathrm{mg} \mathrm{q4w} \mathrm{SC}\end{array}$ & $\begin{array}{l}186 \\
185\end{array}$ & 2 years & $\begin{array}{l}\text { Proportion of patients } \\
\text { who met ASAS } 40 \\
\text { response criteria at } \\
\text { week } 16 \text { (for } \\
\text { secukinumab LD vs. } \\
\text { placebo) or week } 52 \\
\text { (for secukinumab no } \\
\text { LD vs. placebo) }\end{array}$ \\
\hline $\begin{array}{l}\text { SKIPPAIN } \\
{[23]}\end{array}$ & $\begin{array}{l}\mathrm{R}, \mathrm{DB}, \\
\mathrm{PC}\end{array}$ & $\begin{array}{l}\text { Active AS and nr- } \\
\text { axSpA, BASDAI } \\
\text { score } \geq 4 \text {, average } \\
\text { spinal pain } \\
\text { NRS }>4, \\
\text { inadequate response } \\
\text { to } \geq 2 \text { NSAIDs } \\
\text { for } \geq 4 \text { weeks }\end{array}$ & $\begin{array}{l}\text { Placebo } \\
\text { Secukinumab } \\
150 \mathrm{mg} \mathrm{LD}^{\mathrm{c}} \mathrm{SC} \\
\text { Re-randomization } \\
\text { to secukinumab } \\
150 \mathrm{mg} \text { or } \\
300 \mathrm{mg} \mathrm{q} 4 \mathrm{w} \mathrm{SC} \\
\text { at week } 8\end{array}$ & $\begin{array}{l}95 \\
285\end{array}$ & 24 weeks & $\begin{array}{l}\text { Proportion of patients } \\
\text { who achieved average } \\
\text { spinal pain score }<4 \\
\text { on a } 0-10 \text { NRS at } \\
\text { week } 8\end{array}$ \\
\hline
\end{tabular}


Table 1 continued

\begin{tabular}{|c|c|c|c|c|c|c|}
\hline $\begin{array}{l}\text { Study } \\
\text { acronym }\end{array}$ & Design & Patients & Treatments & $N$ & $\begin{array}{l}\text { Total } \\
\text { duration }\end{array}$ & Primary endpoint \\
\hline \multirow[t]{3}{*}{$\begin{array}{c}\text { SURPASS } \\
{[22]}\end{array}$} & \multirow{3}{*}{\multicolumn{2}{|c|}{$\begin{array}{c}\mathrm{R}, \mathrm{PB} \\
\mathrm{AC}\end{array}$}} & $\begin{array}{l}\text { Secukinumab } \mathrm{LD}^{\mathrm{c}} \\
\text { then } 150 \mathrm{mg} \\
\mathrm{q} 4 \mathrm{w} \text { SC }\end{array}$ & $\begin{array}{l}\text { NA } \\
\text { (Ongoing } \\
\text { study; } \\
\text { hence, the } \\
\text { number of } \\
\text { patients is } \\
\text { not } \\
\text { confirmed) }\end{array}$ & 2 years & $\begin{array}{l}\text { Demonstrate superiority } \\
\text { of secukinumab over } \\
\text { adalimumab in } \\
\text { reducing spinal } \\
\text { radiographic } \\
\text { progression (as } \\
\text { measured by } \\
\text { mSASSS) at week } 104\end{array}$ \\
\hline & & & $\begin{array}{l}\text { Secukinumab } \mathrm{LD}^{\mathrm{c}} \\
\text { then } 300 \mathrm{mg} \\
\text { q4w SC }\end{array}$ & NA & & \\
\hline & & & $\begin{array}{l}\text { Adalimumab } \\
\qquad 40 \mathrm{mg} \mathrm{q} 2 \mathrm{w} \text { SC }\end{array}$ & NA & & \\
\hline
\end{tabular}

$A C$ active comparator-controlled, $A S A S 20 / 40$ Assessment of SpondyloArthritis international Society criteria for 20\%/40\% improvement, $B A S D A I$ Bath Ankylosing Spondylitis Disease Activity Index, $D B$ double-blind, $h s C R P$ high-sensitivity C-reactive protein, $I V$ intravenous, $L D$ loading dose, $M R I$ magnetic resonance imaging, $m S A S S S$ modified Stoke Ankylosing Spondylitis Spine Score, $N A$ not available, $n r-a x S p A$ non-radiographic axial spondyloarthritis, $N R S$ numerical rating scale, $N S A I D$ non-steroidal anti-inflammatory drug, $P B$ partially blind, $P C$ placebo-controlled, $P_{S} A$ psoriatic arthritis, $q 2 w$ every 2 weeks, $q 4 w$ every 4 weeks, $R$ randomized, $S C$ subcutaneous, $S I$ sacroiliac, $U L N$ upper limit of normal ${ }^{\mathrm{a}} \mathrm{Of} \geq 4.0 \mathrm{~cm}$ on a $0-10-\mathrm{cm}$ visual analogue scale

${ }^{\mathrm{b}} \mathrm{IV}$ infusion of secukinumab $10 \mathrm{mg} / \mathrm{kg}$ at baseline, week 2 and week 4

'SC injection of secukinumab at baseline, and weeks $1,2,3$, and 4 , at the same dose as given for maintenance therapy

information about the clinical profile of patients who may benefit from secukinumab. The PREVENT study was conducted in patients with nr-axSpA and the population was predominantly naïve to TNF inhibitor therapy [18]; in this study, the primary endpoint of ASAS40 at week 16 was achieved by $41.4 \%$ of TNF-naïve patients who received secukinumab $150 \mathrm{mg}$ with loading doses and $42.2 \%$ of those who received secukinumab $150 \mathrm{mg}$ without loading doses, compared with $29.2 \%$ in the placebo group $(P<0.05$ for each secukinumab group) [18].

The MAXIMISE study was undertaken in patients with axial manifestations of PsA (i.e., BASDAI score $\geq 4$ and spinal pain score $\geq 40$ on a $0-100 \mathrm{~mm}$ visual analogue scale with an inadequate response to at least two NSAIDs), and reported results very similar to those in patients with AS. In MAXIMISE, $66 \%$ of patients receiving secukinumab $150 \mathrm{mg}$ and $63 \%$ of those receiving secukinumab $300 \mathrm{mg}$ achieved ASAS20 response at week 12 , compared with $31 \%$ of patients receiving placebo $(P<0.0001$ for each comparison) [17].

The SKIPPAIN study was specifically conducted to investigate the effect of a bDMARD on pain reduction in axSpA patients. The preliminary (unpublished) data showed that significantly more patients on secukinumab $150 \mathrm{mg}$ had improvements in spinal pain after 8 weeks of treatment than patients on placebo [32 vs. 20\%; odds ratio 1.9 (95\% confidence interval: 1.1-3.3); $P<0.05$ ] [23]. In the second half of 
the study, when all the patients were re-randomized to receive either secukinumab 150 or $300 \mathrm{mg}$, reduction in spinal pain at week 24 was more prominent in patients who were initially randomized to placebo and then switched to secukinumab at week 8 compared with patients who received secukinumab $150 \mathrm{mg}$ at the baseline and were then randomized to secukinumab $150 \mathrm{mg}$ or $300 \mathrm{mg}$ at week 8 [23]. The reduction in spinal pain seen in SKIPPAIN can be considered clinically relevant, as well as statistically significant.

Disease activity scores in the SKIPPAIN study showed a marked improvement in ASDAS-CRP scores from baseline to week 8. A further improvement was noticed at week 24; more patients in the active treatment group achieved ASDAS low disease activity after secukinumab dose escalation compared with those who remained on the same dose [23].

\section{Efficacy in the Long Term}

Long-term data from MEASURE 1 indicate that the improvements in the proportion of patients with ASAS20 are maintained during 2 years of continued secukinumab treatment [28]. After the completion of the 2-year MEASURE 1 study, patients were invited to continue open-label secukinumab treatment; data from this extension phase show that the proportion of patients meeting ASAS20 and ASAS40 criteria was maintained through 3,4 , and 5 years of treatment in patients who continued to take secukinumab [29-31]. Similarly, secukinumab provided sustained increases in the proportion of patients with ASAS20 and ASAS40 over $2-3$ years in the MEASURE 2 study $[32,33]$, over 3 years in MEASURE 3 [34], and over 2 years in MEASURE 4 [20]. The long-term clinical response in MEASURE 4 was similar in the groups who had and had not received a loading dose [20].

A pooled analysis of long-term data from MEASURE 1 and 2 confirmed the long-term clinical benefit of secukinumab; it showed that $24.5 \%$ of patients receiving secukinumab met ASAS criteria for partial remission at 3 years (an increase from $15.4 \%$ at 16 weeks), and $24.5 \%$ met the criteria for inactive disease (an increase from $17.6 \%$ at week 16) [35].
The long-term data from the PREVENT studies have been promising because patients with nr-axSpA receiving open-label secukinumab $150 \mathrm{mg}$ after the first year of treatment [18] showed significant and sustained improvement in the manifestations of nr-axSpA (ASAS40) through 2 years of follow-up (data currently available as an abstract) [36]. A comparison between the long-term data (52 weeks and 104 weeks) for PREVENT and MEASURE studies is shown in Fig. 2.

\section{Efficacy in Improving Symptoms and Patient- Reported Outcomes}

Back pain is a key symptom of axSpA, and has a significant impact on the physical and mental components of a patient's quality of life (QoL) and work productivity [37]. In MEASURE 2, patients reported rapid improvement in spinal pain and nocturnal pain scores after only 1 week of starting secukinumab $150 \mathrm{mg}$; an early improvement in both pain and fatigue occurred in patients with normal or elevated high-sensitivity CRP levels, and in those who had been previously treated with TNF inhibitors and those naïve to TNF inhibitor treatment [38]. These improvements were maintained over 2 years of treatment; for example, $77.6 \%$ of patients receiving secukinumab $150 \mathrm{mg}$ had $\geq 20 \%$ improvement in pain at 16 weeks, and $78.0 \%$ had this level of improvement at 2 years [38].

As described earlier, an improvement in spinal pain and nocturnal pain scores (average spinal pain score $<4$ on a $0-10$ NRS) was observed in the SKIPPAIN study at 8 weeks and further reduction in spinal pain was observed at 24 weeks [23]. Figure 3 illustrates pain reduction outcomes from the MEASURE 2 and SKIPPAIN studies. Such reductions in pain can be considered clinically significant, and are likely to be impactful for patients.

Indeed, in addition to pain assessment, the MEASURE 1 study included a range of patientreported outcome (PRO) measures, including QoL (measured by the Short Form 36 [SF-36], EuroQoL 5-domain [EQ-5D] and Ankylosing Spondylitis Quality of life [ASQoL] questionnaire), fatigue (measured by the Functional Assessment of Chronic Illness Therapy-Fatigue 


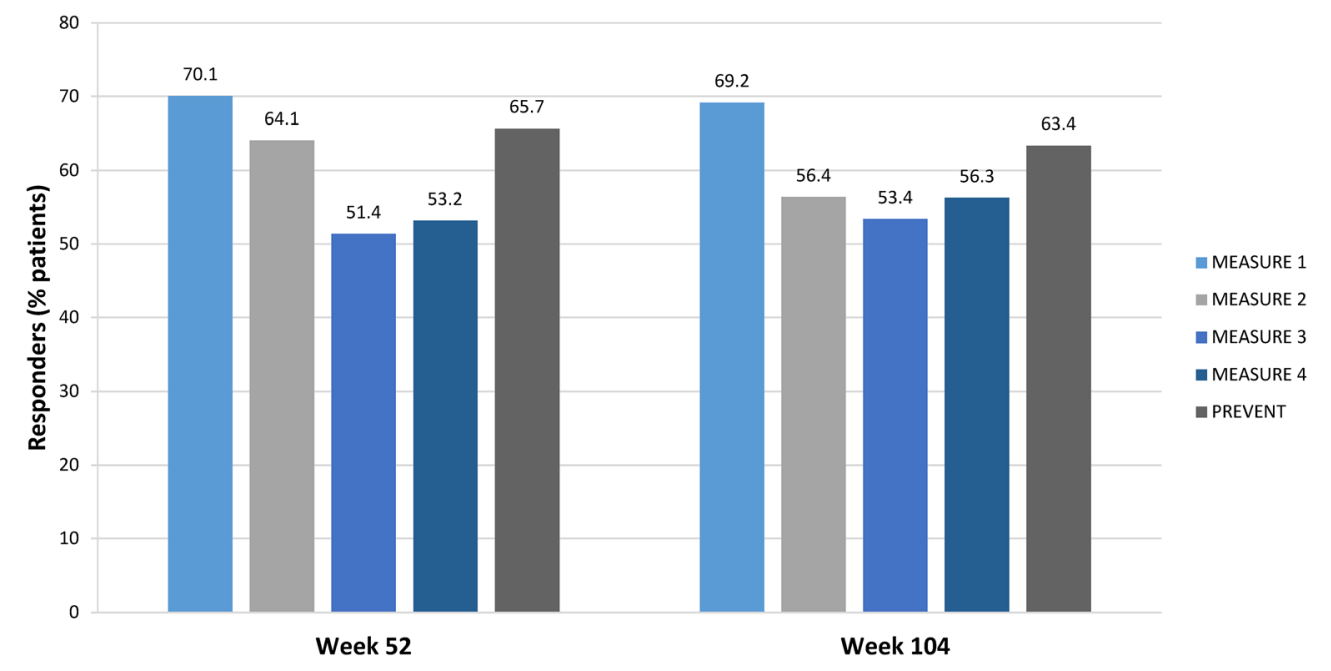

Fig. 2 Long-term efficacy of secukinumab $150 \mathrm{mg}$ in TNF inhibitor-naïve patients in MEASURE and PREVENT trials $[20,29,33,34,36]$. Patients who continued with secukinumab therapy throughout the study period were known as responders. $T N F$ tumor necrosis factor

(b)

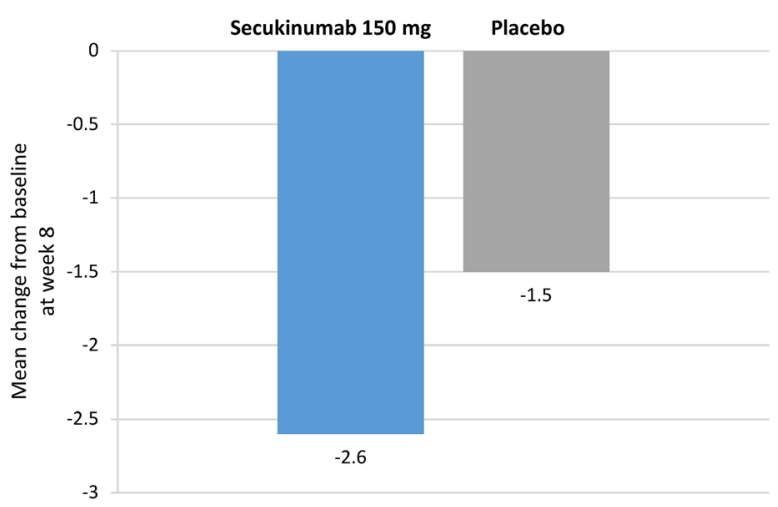

pain) and $\mathbf{b}$ the SKIPPAIN study (assessed using a 11-point spinal pain numerical rating scale ranging from no pain to most intense pain imaginable) $[23,38]$

health decreased in the secukinumab groups between baseline and week 16, but increased among patients in the placebo group [39].

Long-term data from MEASURE 1 and 2 showed that early improvements in fatigue were maintained over 2 years of treatment with secukinumab [40], and a pooled analysis of long-term data from these studies showed that QoL and WPAI-GH scores at 3 years correlated with clinical remission [35]. [31, 39]. Fatigue also decreased significan with both doses of secukinumab versus placebo at week 16 [39]. Time missed from work due to 
Efficacy in Improving Enthesitis and Dactylitis axSpA patients with enthesitis have worse disease severity, spinal mobility, and QoL than those who do not have enthesitis [41], making effective relief of enthesitis symptoms an important clinical goal. A pooled analysis of data from MEASURE 1, 2, 3, and 4 assessed the effect of secukinumab on enthesitis using the Maastricht Ankylosing Spondylitis Enthesitis Score (MASES) on the 693 patients who had this condition at baseline [42]. The mean change from baseline at week 16 in the overall MASES was - 2.4 among patients receiving secukinumab $150 \mathrm{mg}$ compared with -1.9 in the placebo group $(P<0.05)$, and the change in axial MASES was -2.3 compared with -1.8 , respectively $(P<0.05)$. At week $16,40.8 \%$ of patients receiving secukinumab $150 \mathrm{mg}$ had complete resolution of enthesitis (overall MASES of 0 ) compared with $28.9 \%$ in the placebo group $(P<0.01)$, and $42.7 \%$ had complete resolution of axial enthesitis compared with $30.1 \%$ in the placebo $(P<0.001$; Fig. 4$)$ [42]. All improvements in MASES were maintained at week 52 [42].

In a pooled analysis of data from studies in patients with PsA, just over half of the patients with dactylitis at baseline achieved complete resolution during treatment with secukinumab $150 \mathrm{mg}$ (52.1\% in those who had received a loading dose and $52.5 \%$ in those who had not) and in $61.5 \%$ of patients who received secukinumab $300 \mathrm{mg}$ [43].

\section{Impact on Radiographic Progression or Structural Damage}

New bone formation in the axial skeleton, entheses, and peripheral sites are distinctive features of axSpA. A previous inflammation or osteitis in the subchondral bone marrow triggers new bone formation, the progression of which can be radiographically determined $[3,44]$. In AS, the development of new syndesmophytes occurs gradually, with the rate of progression being faster in patients with existing syndesmophytes compared with those without syndesmophytes [45]. New bone formation is stimulated by the complex systems affected by inflammation that includes the wingless proteins/Dikkopf-1 pathway along with secreted frizzled-related proteins and growth factors like bone morphogenetic proteins [44]. The IL-23/IL-17 axis strongly drives this pathogenic process; IL-17A potentially affects osteoblastogenesis depending upon the exposed cell type, differentiation stage, and cytokine exposure (both timing and duration) [46]. As the formation of new bone is a slow process, and it is difficult to visualize the ongoing process radiographically, early suppression of the bony inflammation would be the most effective way to prevent bone formation [3].

A follow-up investigation of the original proof-of-concept phase II study with secukinumab (Fig. 5) [25] found that $87 \%$ of inflammatory changes and $30 \%$ of non-inflammatory (fatty) changes at vertebral edges on magnetic resonance imaging (MRI) resolved during longterm (94 weeks) treatment with intravenous (IV) secukinumab [47]. In addition, encouraging data on the impact of secukinumab on radiographic progression were reported from the MEASURE 1 study [28]. In patients who had matched X-rays at baseline and week 104, the mean change in the mSASSS was 0.3 [28]. Of the 64 secukinumab recipients who had no syndesmophytes on their baseline X-ray, 61 $(95.3 \%)$ remained free of syndesmophytes at week 104; among the 104 who did have syndesmophytes at baseline, only 30\% developed additional new syndesmophytes by week 104 [28]. Moreover, patients who continued to take open-label secukinumab after the completion of the MEASURE 1 study maintained a stable mSASSS through 4 years of treatment, as no radiographic progression was seen in $>80 \%$ of the patients at 2 years [28] and in 79\% patients at 4 years [28, 31].

When these data were compared with a historical cohort of biological-naïve patients receiving NSAIDs, patients treated with secukinumab in MEASURE 1 showed less marked radiographic progression over 2 years, although the between-group difference did not reach statistical significance [48].

In the MAXIMISE study, assessment of inflammation/bone marrow lesions in the spine and sacroiliac joints (Berlin MRI score $\geq 1$ ) at the baseline and at week 12 showed that 


\section{(a) Overall MASES}

n Secukinumab $300 \mathrm{mg}$ - Secukinumab $150 \mathrm{mg}$ ㅁacebo

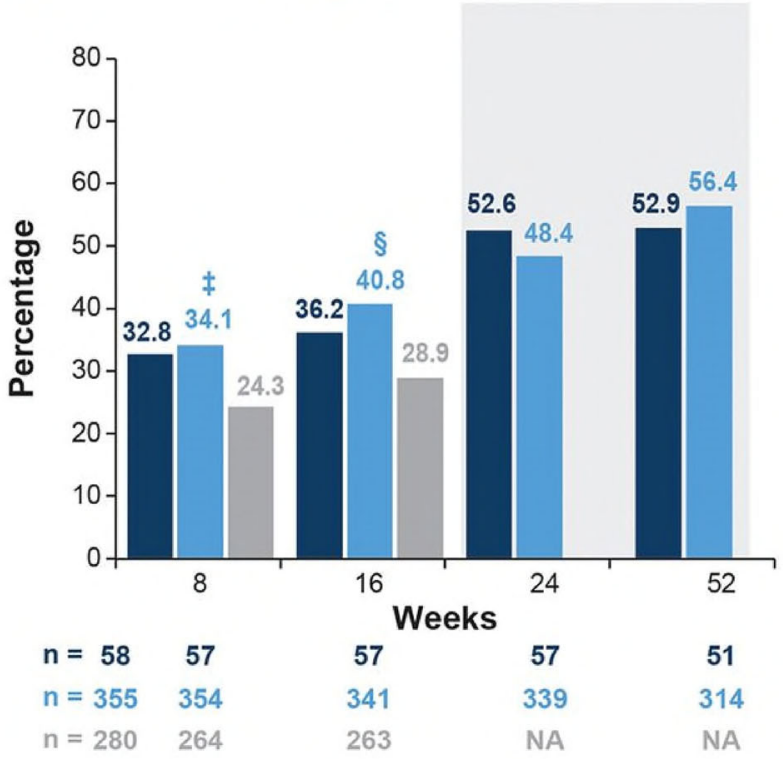

(c) At axial entheseal sites

- Secukinumab $300 \mathrm{mg}$ ! Secukinumab $150 \mathrm{mg}$ - Placebo

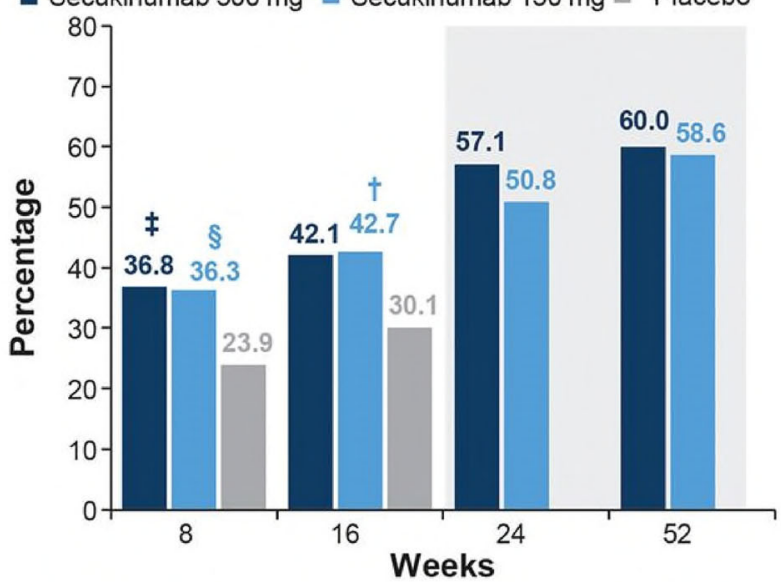

\section{(b) At Achilles tendon sites}

- Secukinumab $300 \mathrm{mg}$ - Secukinumab $150 \mathrm{mg}$ - Placebo

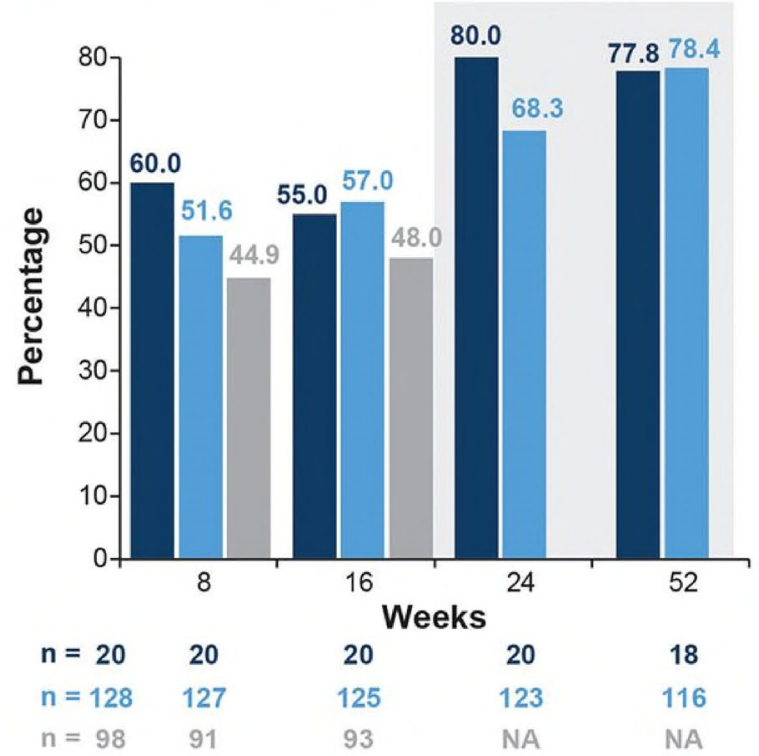

(d) At peripheral entheseal sites

- Secukinumab $300 \mathrm{mg}$ ॥ Secukinumab $150 \mathrm{mg}$ - Placebo

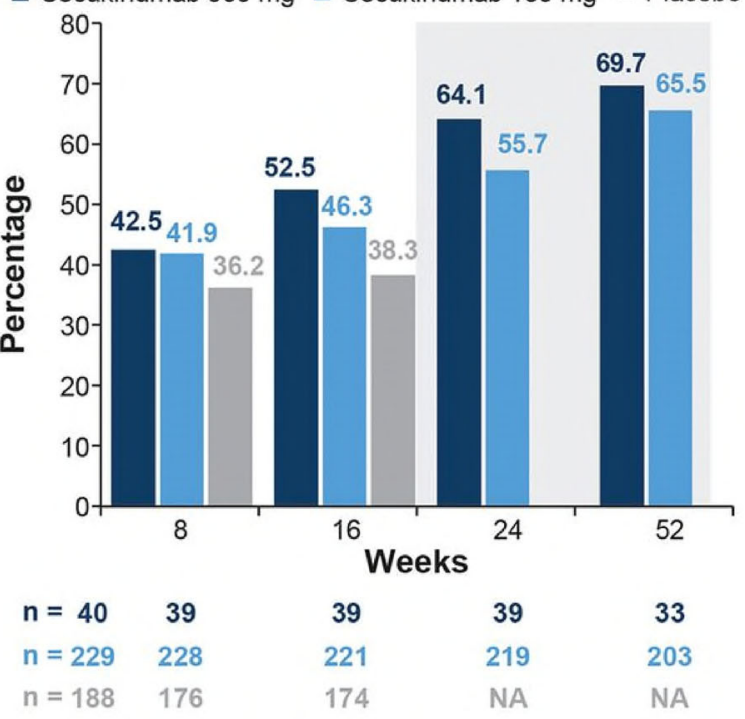

placebo. Non-responder imputation data were used for the analysis up to week 16 and then the observed data were used for analysis through week 52 (shaded area). MASES, Maastricht Ankylosing Spondylitis Enthesitis Score; $N$, total number of patients. Figure reprinted with permission from Schett et al. Copyright 2021 The Journal of Rheumatology

improvement in inflammation at week 12 compared with placebo [49] and this reduction patients receiving secukinumab $150 \mathrm{mg}$ or $300 \mathrm{mg}$ had a statistically significant 


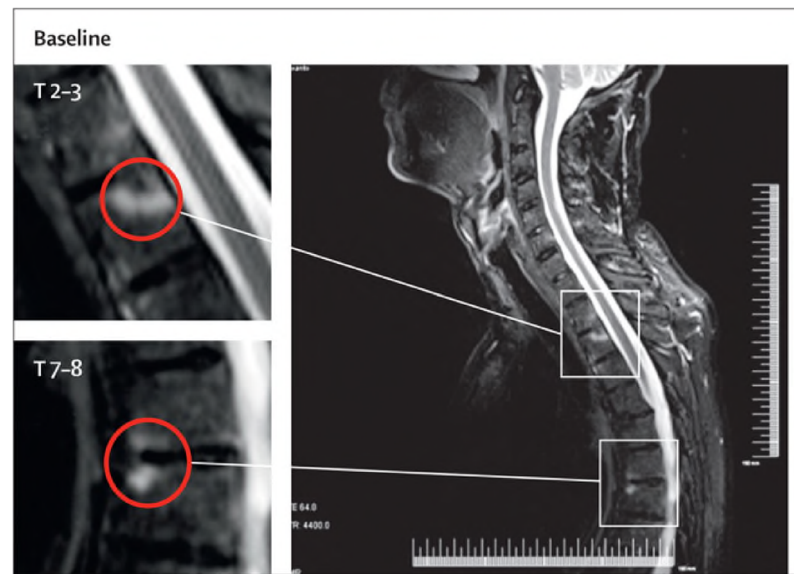

Fig. 5 Proof-of-concept study showing improvement in axial inflammatory lesions in thoracic (T2-T3) and (T7-T8) units at baseline (red circles) and at week 6

in inflammatory MRI lesions was sustained at week 52 [17]. Similarly, in the PREVENT study, secukinumab $150 \mathrm{mg}$, with and without the loading dose, significantly improved the Berlin MRI score in patients with inflammation in their sacroiliac joints versus placebo $(-1.68$ and -1.03 , respectively, vs. -0.39 ; both $P<0.0001)$ at week 16 , and this improvement was maintained through 1 year [18]. The comparative effects of secukinumab and a TNF inhibitor (adalimumab biosimilar) on radiographic progression are currently being assessed in the phase IIIb SURPASS study [22]; planned completion of this study is in December 2021.

\section{Subgroup Analyses}

Estimating the prognosis of patients with axSpA is challenging because the type and severity of symptoms are heterogeneous, and treatment outcome measures are either patient-reported or are assessed by measuring radiographic progression, which may not be feasible in all cases. Miceli-Richard and colleagues investigated the predictive potential of baseline demographic (age, gender, body mass index) and disease characteristics (CRP levels, TNF status, MASES, occiput-to-wall distance, BASMI, and Physician's Global Assessment scores) using logistic regression analysis and machine learning, and their preliminary findings were presented at the ACR conference in 2020 [50]. They found that

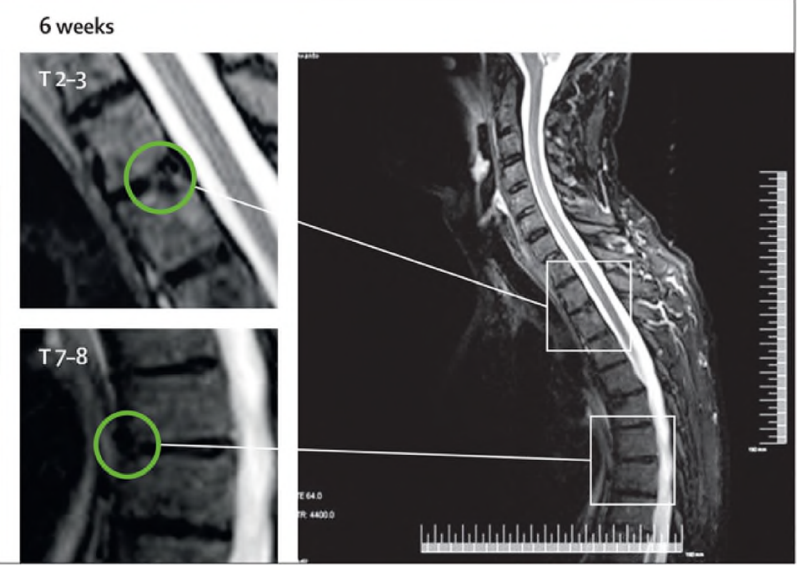

(green circles) in a patient treated with secukinumab [25]. Figure reprinted with permission from Baeten et al. Copyright 2013 Elsevier

factors like younger age, lower body mass index, higher levels of high-sensitive CRP, TNF inhibitor-naïve status, lower occiput-to-wall distance score, and lower MASES score were found to be associated with a better response to secukinumab therapy in patients with AS [50].

In prespecified subgroup analyses of the randomized controlled trials, the magnitude of the benefit with secukinumab $150 \mathrm{mg}$ was greater in TNF inhibitor-naïve than -experienced patients $[9,27]$. While elevated CRP levels are predictive of a better response to TNF inhibitors, there was a consistent benefit in the clinical efficacy of secukinumab, irrespective of baseline CRP levels. Nevertheless, a non-significant improvement in response to secukinumab was observed in patients with elevated baseline CRP levels versus normal baseline levels [51]. The efficacy of secukinumab in improving axial symptoms regardless of peripheral joint involvement is well founded. Findings of a post hoc, hypothesis-generating analysis also found that treatment with secukinumab significantly improved the symptoms of peripheral arthritis, such as swollen and tender joints, in patients with AS (findings presented at the EULAR conference in 2020) [52].

Preliminary data from a large pooled population of patients with AS suggest that the effectiveness of secukinumab was found to be independent of HLA-B27 status. However, 
patients positive for HLA-B27 experienced a non-significant increase in the therapeutic benefit compared with HLA-B27-negative patients [53].

Similarly, recent conference presentations reported that young age resulted in faster attainment of ASAS20/40 and a greater reduction in disease activity measures than older age [54], and that gender had no influence on secukinumab treatment outcomes [55].

Moreover, data from the MEASURE-2J study (in Japanese patients), MEASURE 5 study (70\% Chinese patients) and subgroups of Asian patients participating in MEASURE 1 and 2 demonstrated that the effects of secukinumab were similar in Asian and non-Asian individuals $[19,24,56,57]$.

\section{Real-World Efficacy and Retention}

Randomized clinical trials have excellent internal validity, but careful patient selection means that the results are not always generalizable to a more heterogeneous real-world population. Observational and registry studies, including the European Spondyloarthritis Research Network Collaboration (EuroSpA), have shown that patients with axSpA receiving secukinumab in clinical practice experience statistically significant improvements in a range of disease activity parameters (e.g., BASDAI, ADAS-CRP, CRP and affected joint counts), QoL, pain, and fatigue [58-60]. The ongoing non-interventional AQUILA study is investigating the real-world effectiveness of secukinumab treatment in patients with active AS and PsA. Preliminary reported described improvements in disease activity (e.g., PGA, BASDAI, and CRP) and in physical and mental well-being [Assessment of Spondyloarthritis Health Index (ASAS-HI), Beck's Depression Inventory Version II (BDI-II)] up to 1 year in all patients $[61,62]$. These benefits were seen in more patients with no prior TNF inhibitor treatment than those with prior TNF inhibitor treatment [62].

Persistence with secukinumab treatment is high in the real-world setting. Data from observational and registry studies, including EuroSpA, showed that the 12-month retention rates with secukinumab at any line of treatment were between 68 and $80 \%$ in patients with AS or
PsA (Fig. 6) [58, 59, 63, 64]. Retention was highest when secukinumab was used as the first biological agent (76-84\% at 12 months), but decreased with subsequent lines of treatment (67-75\% as second-line biological and 56-66\% as third-line) $[58,65,66]$. The most common reason for treatment discontinuation in these real-world studies was insufficient efficacy $[58,59,63,66]$, and data from EuroSpA showed that this was also the most common reason for discontinuing TNF inhibitor therapy [58].

Another preliminary report from the AQUILA study showed that the 12-month adherence rate for secukinumab was $64.5 \%$ for AS and $56.0 \%$ for PsA. Comparatively, the persistence rate was higher in biological/biosimilarnaïve patients than -experienced patients, with insufficient response/efficacy and adverse events (AEs) being the most common reasons for treatment discontinuation in both patient groups [67].

\section{Safety}

The safety/tolerability profile of secukinumab in patients with axSpA is consistent with that in patients with plaque psoriasis [9]; the incidence of immunogenicity was low, as evidenced by detection of anti-drug antibodies in only $0.68 \%$ of patients with AS and $0.35 \%$ with PsA [68]. During the placebo-controlled periods of the

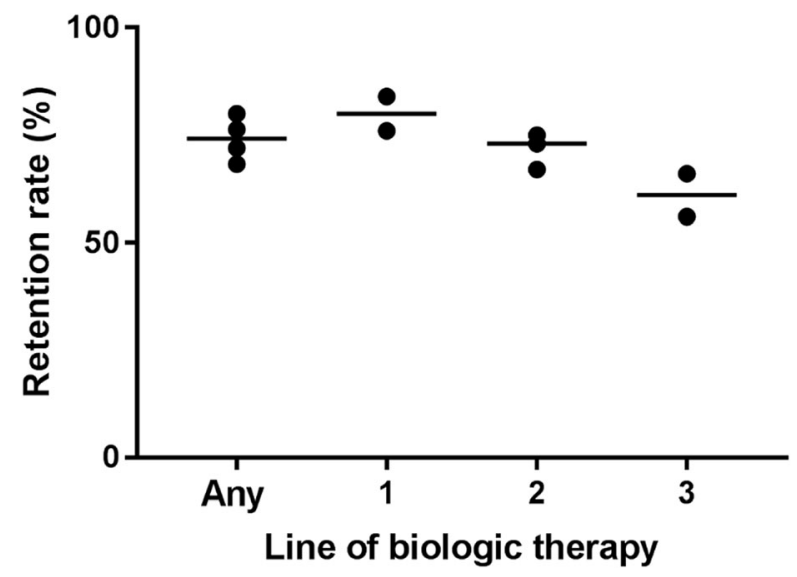

Fig. 6 Twelve-month retention rates with secukinumab in real-world studies [58, 59, 63-66]. Horizontal line indicates median 
randomized controlled trials (i.e., the first $12-16$ weeks), between 46 and $70 \%$ of patients receiving secukinumab and from 44 to $64 \%$ of patients receiving placebo reported AEs; serious AEs (SAEs) were seen in $0-6 \%$ of patients randomized to secukinumab and $1-4 \%$ of patients randomized to placebo [9]. The most common $\mathrm{AE}$ was nasopharyngitis [9].

An integrated safety analysis was undertaken on data from 21 randomized controlled trials with secukinumab, including MEASURE 1, 2, and $3(n=794)$, and post-marketing surveillance data [69]. In patients with AS, the exposure-adjusted incidence rate (EAIR) of any $\mathrm{AE}$ was 140.1 per 100 patient-years, and of any SAE was 6.3 per 100 patient-years (Table 2) [69]. The most common AEs were viral upper respiratory tract infection, headache, diarrhea, and upper respiratory tract infection [69]. The EAIR for uveitis was 1.4 per 100 patient-years in randomised trials, and 0.03 per 100 patient-years in post-marketing surveillance data, indicating no increase in the risk of uveitis during secukinumab treatment in patients with axSpA [70].

Similarly, 5-year data across a range of indications show a low rate of malignancy in patients receiving secukinumab; the EAIR was 0.85 per 100 patient-years, and the observed number of malignancies was comparable to the expected number [71].

The risk of serious infections and opportunistic infections during treatment with secukinumab is also low (summarized in Table 2). There have also been concerns that prolonged biological therapy can increase the risk of tuberculosis (TB) reactivation in patients with latent $\mathrm{TB}$, but a pooled analysis of data across studies in a variety of indications (including the MEASURE 1, 2, 3, and 4 studies) showed no active cases of TB [72]. New latent TB infection was identified as an $\mathrm{AE}$ in 2/977 of the AS patients in this analysis $(0.2 \%$; EAIR 0.08 per 100 patient-years) [72]. However, no cases of TB reactivation were reported in the integrated safety analysis described above [69].

Evidence with secukinumab has shown that the incidence of new-onset IBD is low in patients with axSpA, although these patients are more likely to develop IBD than the general population [73, 74]. A pooled analysis of data from secukinumab randomized controlled trials showed that 13/794 patients with AS developed IBD, including ulcerative colitis in four patients (EAIR 0.2 per 100 patient-years), Crohn's disease in eight (EAIR 0.4) and IBD undefined in one (EAIR 0.1) [73]. Nine events were new-onset cases and four occurred in patients with preexisting IBD. Notably, the risk of IBD development during secukinumab treatment does not increase over time [73]. Real-world data suggest that the risk of IBD development during secukinumab is higher in AS patients with a history of IBD than in those without such a history [74].

Although data on the use of secukinumab in pregnancy are limited, the available evidence has not highlighted a strong signal for adverse pregnancy outcomes [75].

\section{COVID-19}

Data on the risk of coronavirus disease 2019 (COVID-19) in patients receiving secukinumab are currently limited, but case reports indicate that secukinumab treatment does not adversely affect the course of the disease and can be safely continued or reinitiated once the patient has recovered from COVID-19 illness [76-79]. A population-based cohort study of psoriasis patients in Israel indicated that IL-17A inhibitor treatment was not associated with an increased risk of developing COVID-19 infection, hospitalization or mortality compared with methotrexate or with non-systemic/non-immunomodulatory agents [80]. Current recommendations advise continuing biological therapy in patients who do not have severe acute respiratory syndrome coronavirus 2 (SARS-CoV2) infection, and temporarily discontinuing treatment in those who test positive for the infection [81].

Anecdotal data suggest that some patients with psoriasis discontinued treatment with their biological therapy because they feared that it would increase their risk of developing COVID-19 infection [82]. This highlights the need for individualized treatment decisions and good communication between patients and physicians about the risks and benefits of treatment versus no treatment during the COVID-19 pandemic [81, 82]. 
Table 2 Exposure-adjusted incidence rate of selected adverse events in AS patients receiving secukinumab in clinical studies [69]

EAIR $(95 \% \mathrm{CI})$ in AS patients $(n=794)$ per 100 patient-years

Any AE

Any SAE

Any serious infection

Any Candida infection

Inflammatory bowel disease

Uveitis

Major adverse cardiovascular event

Malignancy
$140.1(129.8-151.0)$

$$
\begin{aligned}
& 6.3(5.2-7.6) \\
& 1.2(0.8-1.8) \\
& 0.7(0.4-1.2) \\
& 0.1(0.0-0.3) \\
& 1.4(0.9-2.0) \\
& 0.6(0.3-1.1) \\
& 0.5(0.2-0.9)
\end{aligned}
$$

$A E$ adverse event, $A S$ ankylosing spondylitis, $C I$ confidence interval, $E A I R$ exposure-adjusted incidence rate, $S A E$ serious adverse event

The authors are not aware of any contraindications to the use of COVID-19 vaccines in patients being treated with secukinumab. Indeed, vaccination is highly encouraged in such patients, with EULAR releasing a viewpoint that states "there is no reason to withhold these vaccines from patients with RMDs [rheumatic and musculoskeletal diseases] and patients treated with drugs that influence the immune system" [83].

\section{How does Secukinumab Compare with TNF Inhibitors?}

As mentioned, there is currently only one direct head-to-head clinical study comparing outcomes in axSpA patients taking secukinumab versus those treated with the TNF inhibitor adalimumab, which is currently ongoing [22]. In the absence of direct comparisons, an indirect comparison of secukinumab and adalimumab was made using matching-adjusted data from the MEASURE 1 and 2 studies and from the ATLAS study with adalimumab [84]. There was no difference in ASAS20 or ASAS40 outcomes between secukinumab and adalimumab in the placebo-anchored comparison, but the unanchored comparisons significantly favored secukinumab for ASAS20 at weeks 16 and 24, and for ASAS40 at weeks 24 and 52 [84].
The potential financial impact of treatment of AS with secukinumab and adalimumab in the Finnish healthcare system was compared using a model-based budget impact analysis [85], based on treatment response data from the indirect comparison of these biologicals [84]. Secukinumab was estimated to be more cost effective than adalimumab based on the higher response rate found in the indirect comparison, suggesting that secukinumab may be a more affordable and accessible option than adalimumab [85].

A study of 1-year outcomes in patients receiving secukinumab or TNF inhibitors for AS in five Nordic registries showed that secukinumab and TNF inhibitors were similarly effective when used as first- or second-line biological therapy, but secukinumab was less effective when used in the third-line setting [65]. However, the authors noted that their results could be subject to channeling bias, whereby the secukinumab cohort included more patients with severe (and potentially treatment-resistant) disease, since the secukinumab group included more patients who had received at least three prior biologicals.

The data on the effectiveness of secukinumab and TNF inhibitors as second-line biological therapy was supported by two other observational studies (the Swiss Clinical Quality 
Management cohort [86] and the KOBIO registry in Korea [66]), which compared secukinumab with a TNF-inhibitor in patients with axSpA or AS who had received at least one prior TNF inhibitor. However, unlike the Nordic registry data, the Swiss study showed that secukinumab and a TNF inhibitor were similarly effective whether used as second- or later-line biological treatment [86]. In that cohort (as in the Nordic registries), secukinumab was more likely to be used as the third-line than the second-line biological [86]. The retention rate was similar with secukinumab and TNF inhibitors [86].

Secukinumab can be used in patients with axSpA who also have demyelinating disease (e.g., multiple sclerosis) or heart failure, whereas most TNF inhibitors are contraindicated in patients with moderate or severe heart failure (New York Heart Association class III or IV) [87] and should be used with caution in patients with demyelinating diseases. Although physicians should be vigilant about the potential for tuberculosis and opportunistic infections in any patient taking biological agents, the incidence of these events with secukinumab is very low, and there is no black box warning about these events in the prescribing information for secukinumab as there is for the TNF inhibitors $[8,87]$. Similarly, there is no warning about an increased risk of malignancy with secukinumab, while there is such a warning for TNF inhibitors [8].

\section{CONCLUSIONS}

Data from both randomized trials and observational studies with secukinumab in a range of patients with axSpA continue to accumulate. Randomized trials have established the longterm (5-year) efficacy of secukinumab across multiple domains of axSpA with a favorable and consistent safety profile. While no direct comparative data are yet available, indirect comparisons indicate that secukinumab is as effective as TNF inhibitor therapy in patients with $\operatorname{axSpA}$, and that its safety profile is at least as good as TNF inhibitors. On this basis but acknowledging the limitations of the available evidence (from indirect comparisons, not headto-head studies), the authors' opinion is that secukinumab and TNF inhibitors have comparable efficacy and safety and so both should be considered first-line therapies in patients with axSpA.

\section{ACKNOWLEDGEMENTS}

Funding. Development of this manuscript and associated publication charges (Rapid Service Fee) were funded by Novartis.

Medical writing and Editorial Assistance. We would like to thank Mitali Choudhury of Springer Healthcare Communications who wrote the first and second drafts of this manuscript. This medical writing assistance was funded by Novartis.

Authorship. All named authors meet the International Committee of Medical Journal Editors (ICMJE) criteria for authorship for this article, take responsibility for the integrity of the work as a whole, and have given their approval for this version to be published.

Author Contributions. María Aparicio, Carlos A Guillén-Astete, Clementina López-Medina, Carlos Sastre and Fernando J. Rodríguez Martínez were responsible for the conceptualization and design of the review, critically reviewing and revising all drafts of the review, and approving the final version of the manuscript.

Disclosures. Fernando J. Rodríguez has been a consultant for UCB, Janssen and Novartis. Clementina López-Medina reports speaker fees from UCB, Janssen, AbbVie and Novartis. Maria Aparicio reports speaker fees from UCB, MSD, Pfizer, Lilly, and Novartis. Carlos A GuillénAstete reports speaker fees, commercial and scientific consultancies, and research projects by Novartis. Carlos Sastre is an employee of Novartis. 
Compliance with Ethics Guidelines. This review is based on previously conducted studies and does not contain any studies with human participants or animals performed by any of the authors therefore ethical approval was not required.

Data Availability. Data sharing is not applicable to this article as no datasets were generated or analyzed during the current study.

Open Access. This article is licensed under a Creative Commons Attribution-NonCommercial 4.0 International License, which permits any non-commercial use, sharing, adaptation, distribution and reproduction in any medium or format, as long as you give appropriate credit to the original author(s) and the source, provide a link to the Creative Commons licence, and indicate if changes were made. The images or other third party material in this article are included in the article's Creative Commons licence, unless indicated otherwise in a credit line to the material. If material is not included in the article's Creative Commons licence and your intended use is not permitted by statutory regulation or exceeds the permitted use, you will need to obtain permission directly from the copyright holder. To view a copy of this licence, visit http://creativecommons.org/licenses/by$\mathrm{nc} / 4.0 /$.

\section{REFERENCES}

1. Rudwaleit $M$, van der Heijde D, Landewe R, Akkoc $\mathrm{N}$, Brandt J, Chou CT, Dougados M, et al. The assessment of spondyloarthritis International Society Classification criteria for peripheral spondyloarthritis and for spondyloarthritis in general. Ann Rheum Dis. 2011;70:25-31. https://doi.org/10. 1136/ard.2010.133645.

2. Wallman JK, Kapetanovic MC, Petersson IF, Geborek P, Kristensen LE. Comparison of non-radiographic axial spondyloarthritis and ankylosing spondylitis patients-baseline characteristics, treatment adherence, and development of clinical variables during three years of anti-TNF therapy in clinical practice. Arthritis Res Ther. 2015;17:378. https://doi.org/10.1186/s13075-015-0897-6.
3. Poddubnyy D, Sieper J. Mechanism of new bone formation in axial spondyloarthritis. Curr Rheumatol Rep. 2017;19:55. https://doi.org/10. 1007/s11926-017-0681-5.

4. van der Heijde D, Ramiro S, Landewe R, Baraliakos X, Van den Bosch F, Sepriano A, Regel A, et al. 2016 update of the ASAS-EULAR management recommendations for axial spondyloarthritis. Ann Rheum Dis. 2017;76:978-91. https://doi.org/10.1136/ annrheumdis-2016-210770.

5. Mease PJ, Heijde DV, Karki C, Palmer JB, Liu M, Pandurengan R, Park $\mathrm{Y}$, et al. Characterization of patients with ankylosing spondylitis and nonradiographic axial spondyloarthritis in the US-based Corrona Registry. Arthritis Care Res (Hoboken). 2018;70:1661-70. https://doi.org/10.1002/acr. 23534.

6. Ward MM, Deodhar A, Gensler LS, Dubreuil M, Yu D, Khan MA, Haroon N, et al. 2019 Update of the American College of Rheumatology/Spondylitis Association of America/Spondyloarthritis Research and treatment network recommendations for the treatment of ankylosing spondylitis and nonradiographic axial spondyloarthritis. Arthritis Care Res (Hoboken). 2019;71:1285-99. https://doi.org/10. 1002/acr.24025.

7. European Medicines Agency. Cosentyx (secukinumab). Summary of product characteristics. 2021. https://www.ema.europa.eu/en/documents/ product-information/cosentyx-epar-productinformation_en.pdf. Accessed 03 May 2021.

8. US Food and Drug Administration. Cosentyx (secukinumab) injection, for subcutaneous use. Prescribing information. 2020. https://www. accessdata.fda.gov/drugsatfda_docs/label/2020/ 125504s035lbl.pdf. Accessed 03 May 2021.

9. Blair HA. Secukinumab: a review in ankylosing spondylitis. Drugs. 2019;79:433-43. https://doi. org/10.1007/s40265-019-01075-3.

10. McGonagle DG, McInnes IB, Kirkham BW, Sherlock J, Moots R. The role of IL-17A in axial spondyloarthritis and psoriatic arthritis: recent advances and controversies. Ann Rheum Dis. 2019;78: 1167-78. https://doi.org/10.1136/annrheumdis2019-215356.

11. Groen SS, Sinkeviciute D, Bay-Jensen AC, Thudium CS, Karsdal MA, Thomsen SF, Schett G, et al. Exploring IL-17 in spondyloarthritis for development of novel treatments and biomarkers. Autoimmun Rev. 2021;20: 102760. https://doi.org/ 10.1016/j.autrev.2021.102760.

12. Koenders MI, van den Berg WB. Secukinumab for rheumatology: development and its potential place 
in therapy. Drug Des Devel Ther. 2016;10:2069-80. https://doi.org/10.2147/dddt.S105263.

13. Food and Drug Administration. Cosentyx FDA approval history. 2021. https://www.drugs.com/ history/cosentyx.html. Accessed 31 August 2021.

14. European Medicines Agency. Cosentyx. 2021. https://www.ema.europa.eu/en/medicines/human/ EPAR/cosentyx. Accessed 31 August 2021.

15. Gottlieb AB, Mease PJ, Kirkham B, Nash P, Balsa AC, Combe B, Rech J, et al. Secukinumab efficacy in psoriatic arthritis: machine learning and metaanalysis of four phase 3 trials. J Clin Rheumatol. 2020. https://doi.org/10.1097/RHU. 0000000000001302.

16. Baeten D, Sieper J, Braun J, Baraliakos X, Dougados M, Emery P, Deodhar A, et al. Secukinumab, an interleukin-17A inhibitor, in ankylosing spondylitis. N Engl J Med. 2015;373:2534-48. https://doi. org/10.1056/NEJMoa1505066.

17. Baraliakos X, Gossec L, Pournara E, Jeka S, MeraVarela A, D'Angelo S, Schulz B, et al. Secukinumab in patients with psoriatic arthritis and axial manifestations: results from the double-blind, randomised, phase 3 MAXIMISE trial. Ann Rheum Dis. 2020. https://doi.org/10.1136/annrheumdis-2020218808.

18. Deodhar A, Blanco R, Dokoupilova E, Hall S, Kameda H, Kivitz AJ, Poddubnyy D, et al. Improvement of signs and symptoms of nonradiographic axial spondyloarthritis in patients treated with secukinumab: primary results of a randomized, placebo-controlled phase iii study. Arthritis Rheumatol. 2021;73:110-20. https://doi.org/10. 1002/art.41477.

19. Huang F, Sun F, Wan WG, Wu LJ, Dong LL, Zhang $\mathrm{X}$, Kim $\mathrm{TH}$, et al. Secukinumab provided significant and sustained improvement in the signs and symptoms of ankylosing spondylitis: results from the 52-week, Phase III China-centric study, MEASURE 5. Chin Med J (Engl). 2020;133:2521-31. https://doi.org/10.1097/CM9.0000000000001099.

20. Kivitz AJ, Wagner U, Dokoupilova E, Supronik J, Martin R, Talloczy Z, Richards HB, et al. Efficacy and safety of secukinumab $150 \mathrm{mg}$ with and without loading regimen in ankylosing spondylitis: 104-week results from MEASURE 4 study. Rheumatol Ther. 2018;5:447-62. https://doi.org/10.1007/ s40744-018-0123-5.

21. Pavelka K, Kivitz A, Dokoupilova E, Blanco R, Maradiaga M, Tahir H, Pricop L, et al. Efficacy, safety, and tolerability of secukinumab in patients with active ankylosing spondylitis: a randomized, double-blind phase 3 study, MEASURE 3. Arthritis
Res Ther. 2017;19:285. https://doi.org/10.1186/ s13075-017-1490-y.

22. Baraliakos X, Ostergaard M, Gensler LS, Poddubnyy D, Lee EY, Kiltz U, Martin R, et al. Comparison of the effects of secukinumab and adalimumab biosimilar on radiographic progression in patients with ankylosing spondylitis: design of a randomized, phase IIIb study (SURPASS). Clin Drug Investig. 2020;40:269-78. https://doi.org/10.1007/ s40261-020-00886-7.

23. Marzo-Ortega H, Perella C, Poddubnyy D, Pournara E, Zielińska A, Baranauskaite A, Sadhu S, et al. P188 Secukinumab provides significant improvement of spinal pain and lowers disease activity in patients with axial spondyloarthritis: 24-week results from a randomised controlled Phase $3 \mathrm{~b}$ trial. Rheumatology. 2021. https://doi.org/10.1093/rheumatology/ keab247.183.

24. Kishimoto M, Taniguchi A, Fujishige A, Kaneko S, Haemmerle S, Porter BO, Kobayashi S. Efficacy and safety of secukinumab in Japanese patients with active ankylosing spondylitis: 24-week results from an open-label phase 3 study (MEASURE 2-J). Mod Rheumatol. 2020;30:132-40. https://doi.org/10. $1080 / 14397595.2018 .1538004$.

25. Baeten D, Baraliakos X, Braun J, Sieper J, Emery P, van der Heijde D, McInnes I, et al. Anti-interleukin17A monoclonal antibody secukinumab in treatment of ankylosing spondylitis: a randomised, double-blind, placebo-controlled trial. Lancet. 2013;382:1705-13. https://doi.org/10.1016/S01406736(13)61134-4.

26. Katsevman GA, Mariscal G, Barrios C, DomenechFernandez P, Ziembinski C, Bhatia S. Efficacy and safety of anti-interleukin-17A monoclonal antibody secukinumab in treatment of ankylosing spondylitis: a meta-analysis. Monoclon Antib Immunodiagn Immunother. 2020;39:160-6. https://doi.org/10. 1089/mab.2020.0022.

27. Zhou Y, Ma J, Ge J, Wang B, Yue D, Wang W. Shortterm efficacy and safety of secukinumab for ankylosing spondylitis: a systematic review and metaanalysis of RCTs. Mediators Inflamm. 2020;2020: 1639016. https://doi.org/10.1155/2020/1639016.

28. Braun J, Baraliakos X, Deodhar A, Baeten D, Sieper J, Emery P, Readie A, et al. Effect of secukinumab on clinical and radiographic outcomes in ankylosing spondylitis: 2-year results from the randomised phase III MEASURE 1 study. Ann Rheum Dis. 2017;76:1070-7. https://doi.org/10.1136/ annrheumdis-2016-209730.

29. Baraliakos X, Braun J, Deodhar A, Poddubnyy D, Kivitz A, Tahir H, Van den Bosch F, et al. Long-term efficacy and safety of secukinumab $150 \mathrm{mg}$ in 
ankylosing spondylitis: 5-year results from the phase III MEASURE 1 extension study. RMD Open. 2019;5: e001005. https://doi.org/10.1136/ rmdopen-2019-001005.

30. Baraliakos X, Kivitz AJ, Deodhar AA, Braun J, Wei JC, Delicha EM, Talloczy Z, et al. Long-term effects of interleukin-17A inhibition with secukinumab in active ankylosing spondylitis: 3-year efficacy and safety results from an extension of the Phase 3 MEASURE 1 trial. Clin Exp Rheumatol. 2018;36: $50-5$.

31. Braun J, Baraliakos X, Deodhar A, Poddubnyy D, Emery P, Delicha EM, Talloczy Z, et al. Secukinumab shows sustained efficacy and low structural progression in ankylosing spondylitis: 4-year results from the MEASURE 1 study. Rheumatology (Oxford). 2019;58:859-68. https://doi.org/10.1093/ rheumatology/key375.

32. Marzo-Ortega H, Sieper J, Kivitz A, Blanco R, Cohen M, Delicha EM, Rohrer S, et al. Secukinumab provides sustained improvements in the signs and symptoms of active ankylosing spondylitis with high retention rate: 3-year results from the phase III trial, MEASURE 2. RMD Open. 2017;3: e000592. https://doi.org/10.1136/rmdopen-2017-000592.

33. Marzo-Ortega H, Sieper J, Kivitz A, Blanco R, Cohen M, Martin R, Readie A, et al. Secukinumab and sustained improvement in signs and symptoms of patients with active ankylosing spondylitis through two years: results from a phase III study. Arthritis Care Res (Hoboken). 2017;69:1020-9. https://doi. org/10.1002/acr.23233.

34. Pavelka K, Kivitz AJ, Dokoupilova E, Blanco R, Maradiaga M, Tahir H, Wang Y, et al. Secukinumab $150 / 300 \mathrm{mg}$ provides sustained improvements in the signs and symptoms of active ankylosing spondylitis: 3-year results from the phase 3 MEASURE 3 study. ACR Open Rheumatol. 2020;2: 119-27. https://doi.org/10.1002/acr2.11102.

35. Baraliakos X, Van den Bosch F, Machado PM, Gensler LS, Marzo-Ortega H, Sherif B, Quebe-Fehling $\mathrm{E}$, et al. Achievement of remission endpoints with secukinumab over 3 years in active ankylosing spondylitis: pooled analysis of two phase 3 studies. Rheumatol Ther. 2021;8:273-88. https://doi.org/ 10.1007/s40744-020-00269-6.

36. Poddubnyy D, Deodhar A, Baraliakos X, Blanco R, Dokoupilova E, Hall S, Kivitz A, et al. POS0900 secukinumab $150 \mathrm{mg}$ provides sustained improvement in signs and symptoms of non-radiographic axial spondyloarthritis: 2-year results from the PREVENT study. Ann Rheum Dis. 2021;80:707. https://doi.org/10.1136/annrheumdis-2021-eular. 143.
37. van Lunteren $M$, Scharloo $M$, Ez-Zaitouni $Z$, de Koning A, Landewe R, Fongen C, Ramonda R, et al. The impact of illness perceptions and coping on the association between back pain and health outcomes in patients suspected of having axial spondyloarthritis: data from the spondyloarthritis caught early cohort. Arthritis Care Res (Hoboken). 2018;70: 1829-39. https://doi.org/10.1002/acr.23566.

38. Deodhar A, Conaghan PG, Kvien TK, Strand V, Sherif B, Porter B, Jugl SM, et al. Secukinumab provides rapid and persistent relief in pain and fatigue symptoms in patients with ankylosing spondylitis irrespective of baseline C-reactive protein levels or prior tumour necrosis factor inhibitor therapy: 2-year data from the MEASURE 2 study. Clin Exp Rheumatol. 2019;37:260-9.

39. Deodhar AA, Dougados M, Baeten DL, ChengChung Wei J, Geusens P, Readie A, Richards HB, et al. Effect of secukinumab on patient-reported outcomes in patients with active ankylosing spondylitis: a phase III randomized trial (MEASURE 1). Arthritis Rheumatol. 2016;68:2901-10. https:// doi.org/10.1002/art.39805.

40. Kvien TK, Conaghan PG, Gossec L, Strand V, Ostergaard M, Poddubnyy D, Williams N, et al. Secukinumab provides sustained reduction in fatigue in patients with ankylosing spondylitis: longterm results of two phase III randomized controlled trials. Arthritis Care Res (Hoboken). 2020. https:// doi.org/10.1002/acr.24517.

41. Mease PJ, Liu M, Rebello S, Hua W, McLean RR, Yi E, Park Y, et al. Characterization of patients with axial spondyloarthritis by enthesitis presence: data from the Corrona Psoriatic Arthritis/Spondyloarthritis Registry. ACR Open Rheumatol. 2020;2:449-56. https://doi.org/10.1002/acr2.11154.

42. Schett G, Baraliakos X, Van den Bosch F, Deodhar A, Ostergaard M, Das Gupta A, Mpofu S, et al. Secukinumab efficacy on enthesitis in patients with ankylosing spondylitis: pooled analysis of four pivotal phase 3 studies. J Rheumatol. 2021;48: 1251-8. https://doi.org/10.3899/jrheum.201111.

43. Orbai AM, McInnes IB, Coates LC, Husni ME, Gladman DD, Gossec L, Pricop L, et al. Effect of secukinumab on the different GRAPPA-OMERACT core domains in psoriatic arthritis: a pooled analysis of 2049 patients. J Rheumatol. 2020;47:854-64. https://doi.org/10.3899/jrheum.190507.

44. Furst DE, Louie JS. Targeting inflammatory pathways in axial spondyloarthritis. Arthritis Res Ther. 2019;21:135. https://doi.org/10.1186/s13075-0191885-z.

45. van Tubergen A, Ramiro S, van der Heijde D, Dougados M, Mielants H, Landewé R. Development 
of new syndesmophytes and bridges in ankylosing spondylitis and their predictors: a longitudinal study. Ann Rheum Dis. 2012;71:518-23. https:// doi.org/10.1136/annrheumdis-2011-200411.

46. Ceribelli A, Motta F, Vecellio M, Isailovic N, Ciccia F, Selmi C. Clinical trials supporting the role of the IL-17/IL-23 axis in axial spondyloarthritis. Front Immunol. 2021. https://doi.org/10.3389/fimmu. 2021.622770 .

47. Baraliakos X, Borah B, Braun J, Baeten D, Laurent D, Sieper J, Emery P, et al. Long-term effects of secukinumab on MRI findings in relation to clinical efficacy in subjects with active ankylosing spondylitis: an observational study. Ann Rheum Dis. 2016;75:408-12. https://doi.org/10.1136/ annrheumdis-2015-207544.

48. Braun J, Haibel H, de Hooge M, Landewe R, Rudwaleit M, Fox T, Readie A, et al. Spinal radiographic progression over 2 years in ankylosing spondylitis patients treated with secukinumab: a historical cohort comparison. Arthritis Res Ther. 2019;21:142. https://doi.org/10.1186/s13075-019-1911-1.

49. Baraliakos X, Gossec L, Pournara E, Jeka S, Blanco R, D'angelo S, Schett G, et al. OP0053 Secukinumab improves clinical and imaging outcomes in patients with psoriatic arthritis and axial manifestations with inadequate response to NSAIDs: week 52 results from the MAXIMISE trial. Ann Rheum Dis. 2020;79:35-6. https://doi.org/10.1136/ annrheumdis-2020-eular.638.

50. Miceli-Richard C, Poddubnyy D, Deodhar A, Bao W, Parman C, Porter B, Pournara E. Predictors of response in secukinumab-treated patients with ankylosing spondylitis: logistic regression and machine learning analyses [abstract]. Arthritis Rheumatol. 2020; 72 (suppl 10). https:// acrabstracts.org/abstract/predictors-of-response-insecukinumab-treated-patients-with-ankylosingspondylitis-logistic-regression-and-machinelearning-analyses/.

51. Braun J, Deodhar A, Landewe R, Baraliakos X, Miceli-Richard C, Sieper J, Quebe-Fehling E, et al. Impact of baseline C-reactive protein levels on the response to secukinumab in ankylosing spondylitis: 3 -year pooled data from two phase III studies. RMD Open. 2018;4: e000749. https://doi.org/10.1136/ rmdopen-2018-000749.

52. Mease PJ, Deodhar A, Calheiros R, Meng X, Fox T, Baraliakos X. THU0397 Symptoms of peripheral arthritis are significantly improved in patients with ankylosing spondylitis treated with secukinumab. Ann Rheum Dis. 2020;79:434-5. https://doi.org/10. 1136/annrheumdis-2020-eular.2217.
53. Deodhar A, Mease PJ, Poddubnyy D, Calheiros R, Meng X, Strand V, Magrey M. FRI0271 impact of HLA-B27 status on clinical outcomes among patients with ankylosing spondylitis treated with secukinumab. Ann Rheum Dis. 2020;79:721. https://doi.org/10.1136/annrheumdis-2020-eular. 1448.

54. Deodhar A, Mease P, Machado P, Pournara E, Meng X, Strand V, Magrey M. 0350 The impact of age and time since diagnosis on response to treatment with secukinumab in pooled week 52 data from 4 phase 3 studies in patients with ankylosing spondylitis [abstract]. Arthritis Rheumatol. 2020; 72 (suppl 10). https://acrabstracts.org/abstract/the-impact-of-ageand-time-since-diagnosis-on-response-totreatment-with-secukinumab-in-pooled-week-52data-from-4-phase-3-studies-in-patients-withankylosing-spondylitis/.

55. Horst-Bruinsma I, Richard CM, Braun J, Bao W, Porter B, Pournara E. FRI0418 secukinumab provided similar efficacy in males and females with active ankylosing spondylitis over 52 weeks: post hoc pooled analysis of the MEASURE trials. Ann Rheum Dis. 2019;78:897-8. https://doi.org/10. 1136/annrheumdis-2019-eular.1834.

56. Tseng JC, Wei JC, Deodhar A, Martin R, Porter B, McCreddin S, Talloczy Z. Secukinumab demonstrates sustained efficacy and safety in a Taiwanese subpopulation with active ankylosing spondylitis: four-Year results from a phase 3 study, MEASURE 1. Front Immunol. 2020;11: 561748. https://doi.org/ 10.3389/fimmu.2020.561748.

57. Wei JC, Baeten D, Sieper J, Deodhar A, Bhosekar V, Martin R, Porter B. Efficacy and safety of secukinumab in Asian patients with active ankylosing spondylitis: 52-week pooled results from two phase 3 studies. Int J Rheum Dis. 2017;20:589-96. https:// doi.org/10.1111/1756-185X.13094.

58. Michelsen B, Lindstrom U, Codreanu C, Ciurea A, Zavada J, Loft AG, Pombo-Suarez M, et al. Drug retention, inactive disease and response rates in 1860 patients with axial spondyloarthritis initiating secukinumab treatment: routine care data from 13 registries in the EuroSpA collaboration. RMD Open. 2020;2020:6. https://doi.org/10.1136/rmdopen2020-001280.

59. Chimenti MS, Fonti GL, Conigliaro P, Sunzini F, Scrivo R, Navarini L, Triggianese P, et al. One-year effectiveness, retention rate, and safety of secukinumab in ankylosing spondylitis and psoriatic arthritis: a real-life multicenter study. Expert Opin Biol Ther. 2020;20:813-21. https://doi.org/10.1080/ 14712598.2020 .1761957$.

60. Williams T, Wadeley A, Bond D, Cavill C, Freeth M, Sengupta R. Real-world experience of secukinumab 
treatment for ankylosing spondylitis at the Royal National Hospital for Rheumatic Diseases. Bath Clin Rheumatol. 2020;39:1501-4. https://doi.org/ 10.1007/s10067-020-04944-5.

61. Kiltz U, Peterlik D, Winkelmann V, Tony H-P, AQUILA Study Group. FRI0406 AQUILA study in Germany-real world data on secukinumab's effectiveness in ankylosing spondylitis patients-results from an interim analysis. Ann Rheum Dis. 2019;78: 890.

62. Kiltz U, Brandt-Juergens J, Kästner P, Riechers E, Peterlik D, Tony H-P. THU0399 How do TNF-alphainhibitors in medical history affect patient reported outcomes and retention in ankylosing spondylitis patients treated with secukinumab in real world?German AQUILA study. Ann Rheum Dis. 2020;76: 436-7.

63. Conesa-Nicolas E, Garcia-Lagunar MH, Nunez-Bracamonte S, Garcia-Simon MS, Mira-Sirvent MC. Persistence of secukinumab in patients with psoriasis, psoriatic arthritis, and ankylosing spondylitis. Farm Hosp. 2020;45:16-21. https://doi.org/10. 7399/fh.11465.

64. Gentileschi S, Rigante D, Sota J, Lopalco G, Giannotta MG, Emmi G, Di Scala G, et al. Long-term effectiveness of secukinumab in patients with axial spondyloarthritis. Mediat Inflamm. 2020;2020: 6983272. https://doi.org/10.1155/2020/6983272.

65. Glintborg B, Lindstrom U, Di Giuseppe D, Provan SA, Gudbjornsson B, Hetland ML, Michelsen B, et al. One-year treatment outcomes of secukinumab versus tumor necrosis factor inhibitors in spondyloarthritis. Arthritis Care Res (Hoboken). 2020. https://doi.org/10.1002/acr.24523.

66. Ki Min H, Kim HR, Lee SH, Hong YS, Kim MY, Park $\mathrm{SH}$, Kang KY. Retention rate and effectiveness of secukinumab vs. TNF inhibitor in ankylosing spondylitis patients with prior TNF inhibitor exposure. Rheumatology (Oxford). 2021. https:// doi.org/10.1093/rheumatology/keab245.

67. Kiltz U, Peterlik D, Winkelmann V, Tony H-P, AQUILA Study Group. AB0705 AQUILA study in Germany-real world adherence and persistence of secukinumab treatment in ankylosing spondylitis and psoriatic arthritis patients-an interim analysis. Ann Rheum Dis. 2019;78:1814-5.

68. Deodhar AA, Gladman DD, McInnes IB, Strand V, Ren M, Spindeldreher S, Pricop L et al. Secukinumab immunogenicity in patients with psoriatic arthritis and ankylosing spondylitis during a 52-week treatment period [abstract]. Arthritis Rheumatol. 2018; 70 (suppl 10). https:// acrabstracts.org/abstract/secukinumabimmunogenicity-in-patients-with-psoriatic- arthritis-and-ankylosing-spondylitis-during-a-52week-treatment-period/.

69. Deodhar A, Mease PJ, McInnes IB, Baraliakos X, Reich K, Blauvelt A, Leonardi C, et al. Long-term safety of secukinumab in patients with moderateto-severe plaque psoriasis, psoriatic arthritis, and ankylosing spondylitis: integrated pooled clinical trial and post-marketing surveillance data. Arthritis Res Ther. 2019;21:111. https://doi.org/10.1186/ s13075-019-1882-2.

70. Deodhar AA, Miceli-Richard C, Baraliakos X, MarzoOrtega H, Gladman DD, Blanco R, Das Gupta A, et al. Incidence of uveitis in secukinumab-treated patients with ankylosing spondylitis: pooled data analysis from three phase 3 studies. ACR Open Rheumatol. 2020;2:294-9. https://doi.org/10.1002/ acr2.11139.

71. Lebwohl M, Deodhar A, Griffiths CEM, Menter MA, Poddubnyy D, Bao W, Jehl V, et al. The risk of malignancy in secukinumab-treated psoriasis, psoriatic arthritis and ankylosing spondylitis patients: analysis of up to five-year clinical trial and postmarketing surveillance data. Br J Dermatol. 2021. https://doi.org/10.1111/bjd.20136.

72. Elewski BE, Baddley JW, Deodhar AA, Magrey M, Rich PA, Soriano ER, Soung J, et al. Association of secukinumab treatment with tuberculosis reactivation in patients with psoriasis, psoriatic arthritis, or ankylosing spondylitis. JAMA Dermatol. 2021;157: 43-51. https://doi.org/10.1001/jamadermatol. 2020.3257.

73. Schreiber S, Colombel JF, Feagan BG, Reich K, Deodhar AA, McInnes IB, Porter B, et al. Incidence rates of inflammatory bowel disease in patients with psoriasis, psoriatic arthritis and ankylosing spondylitis treated with secukinumab: a retrospective analysis of pooled data from 21 clinical trials. Ann Rheum Dis. 2019;78:473-9. https://doi.org/10. 1136/annrheumdis-2018-214273.

74. Onac IA, Clarke BD, Tacu C, Lloyd M, Hajela V, Batty T, Thoroughgood J, et al. Secukinumab as a potential trigger of inflammatory bowel disease in ankylosing spondylitis or psoriatic arthritis patients. Rheumatology (Oxford). 2021. https://doi. org/10.1093/rheumatology/keab193.

75. Warren RB, Reich K, Langley RG, Strober B, Gladman D, Deodhar A, Bachhuber T, et al. Secukinumab in pregnancy: outcomes in psoriasis, psoriatic arthritis and ankylosing spondylitis from the global safety database. Br J Dermatol. 2018;179: 1205-7. https://doi.org/10.1111/bjd.16901.

76. Coskun Benlidayi I, Kurtaran B, Tirasci E, Guzel R. Coronavirus disease 2019 (COVID-19) in a patient with ankylosing spondylitis treated with 
secukinumab: a case-based review. Rheumatol Int. 2020;40:1707-16. https://doi.org/10.1007/s00296020-04635-z.

77. Di Lernia V, Bombonato C, Motolese A. COVID-19 in an elderly patient treated with secukinumab. Dermatol Ther. 2020;33: e13580. https://doi.org/ 10.1111/dth.13580.

78. Mugheddu C, Sanna S, Atzori L, Rongioletti F. Safety of secukinumab treatment in COVID-19 affected psoriatic patients. Dermatol Ther. 2021;34: e14710. https://doi.org/10.1111/dth.14710.

79. Queiro Silva R, Armesto S, Gonzalez Vela C, Naharro Fernandez C, Gonzalez-Gay MA. COVID19 patients with psoriasis and psoriatic arthritis on biologic immunosuppressant therapy vs. apremilast in North Spain. Dermatol Ther. 2020;33: e13961. https://doi.org/10.1111/dth.13961.

80. Kridin K, Schonmann Y, Solomon A, Damiani G, Tzur Bitan D, Onn E, Weinstein $\mathrm{O}$, et al. Risk of COVID-19 infection, hospitalization, and mortality in patients with psoriasis treated by interleukin-17 inhibitors. J Dermatolog Treat. 2021. https://doi. org/10.1080/09546634.2021.1905766.

81. Gadarowski MB, Balogh EA, Bashyam AM, Feldman SR. Examining recommendations for the use of biologics and other systemic therapies during COVID-19: a review and comparison of available dermatology guidelines and patient registries. J Dermatolog Treat. 2020. https://doi.org/10.1080/ 09546634.2020.1808154.

82. Polat Ekinci A, Pehlivan G, Gokalp MO. Surveillance of psoriatic patients on biologic treatment during the COVID-19 pandemic: a single-center experience. Dermatol Ther. 2021;34: e14700. https://doi.org/10.1111/dth.14700.

83. Bijlsma JW. EULAR December 2020 view points on SARS-CoV-2 vaccination in patients with RMDs. Ann Rheum Dis. 2021. https://doi.org/10.1136/ annrheumdis-2020-219773.

84. Maksymowych WP, Strand V, Nash P, Yazici Y, Thom H, Hunger M, Kalyvas C, et al. Comparative effectiveness of secukinumab and adalimumab in ankylosing spondylitis as assessed by matching-adjusted indirect comparison. Eur J Rheumatol. 2018;5:216-23. https://doi.org/10.5152/eurjrheum. 2018.18162.

85. Purmonen T, Tormalehto S, Wahlman H, Puolakka K. Budget impact analysis of secukinumab versus adalimumab in the treatment of ankylosing spondylitis. J Med Econ. 2019;22:151-7. https://doi. org/10.1080/13696998.2018.1551227.

86. Micheroli R, Tellenbach C, Scherer A, Burki K, Niederman K, Nissen MJ, Zufferey P, et al. Effectiveness of secukinumab versus an alternative TNF inhibitor in patients with axial spondyloarthritis previously exposed to TNF inhibitors in the Swiss Clinical Quality Management cohort. Ann Rheum Dis. 2020;79:1203-9. https://doi.org/10.1136/ annrheumdis-2019-215934.

87. Lis $\mathrm{K}$, Kuzawinska O, Balkowiec-Iskra E. Tumor necrosis factor inhibitors-state of knowledge. Arch Med Sci. 2014;10:1175-85. https://doi.org/10.5114/ aoms.2014.47827. 